\title{
Malaria risk in the highlands of western Kenya: an entomological perspective
}

\author{
C.J.M. Koenraadt ${ }^{\#}$ and A.K. Githeko ${ }^{\#}$
}

\begin{abstract}
Epidemics of malaria seem to occur more frequently in the highlands of eastern Africa. In western Kenya, for example, epidemics have spread from 3 to 15 districts. There is an increasing debate on the possible causes of this phenomenon, but detailed field studies are lacking to test a number of basic hypotheses. In this chapter, we review some of the results from a comparative field study on malaria risk in a highland and a lowland area in western Kenya. Questions that will be addressed in this chapter are: under which conditions may malaria epidemics occur in highland areas and to what extent is the situation in western Kenya comparable to other highland areas in the region?
\end{abstract}

Keywords: Anopheles gambiae; Anopheles arabiensis; malaria risk; Kenya; environmental change; highlands

\section{Introduction}

The intimate relationships between parasites or viruses, and their vectors, hosts and natural environment make this ecological web extremely sensitive to disturbances. Therefore, environmental and socio-economic changes, such as global warming, deforestation, commercial development and construction of water-control systems, are expected to exert a huge impact on the transmission of viral and parasitic diseases, such as Rift Valley fever, yellow fever, schistosomiasis, filariasis and malaria (Githeko et al. 2000; Martens, Slooff and Jackson 1997; Martens 1998; Patz and Reisen 2001; Patz et al. 2000). The diseases may spread to areas where they did not occur before or the current situation may aggravate in areas where the disease is already endemic.

Theoretically, one infective mosquito bite is enough to acquire an episode of malaria. Clinical symptoms may range from mild, such as fever, abdominal pains, nausea and vomiting, to severe and life-threatening, such as anaemia, renal disfunction and cerebral malaria (Warrell 1993). However, not everybody who gets an infection becomes seriously ill or dies, because this depends on the degree of immunity of the individual. A substantial level of immunity to malaria may already be acquired after one or two infective bites. The antigenic variation of $P$. falciparum (i.e.

\footnotetext{
\# Laboratory of Entomology, Wageningen University, The Netherlands; present address: AFRIMS Entomology Laboratory, 2 soi 15, Rachdamnoen road 1, Nai Muang, Muang, Kamphaeng Phet 62000, Thailand. E-mail: cjmkoenraadt@ucdavis.edu

\#伊ya Medical Research Institute, P.O. Box 1578, Kisumu, Kenya. E-mail: agitheko@kisian.mimcom.net
} 
the variation in antigens expressed at the surface of the infected red blood cell) is thought to play an important role in this (Day and Marsh 1991; Gupta et al. 1999; Roberts et al. 1993). During their first 3 to 6 months of life, infants have a protective immunity through antibodies they obtained from their mother. After this period, they will build up protective immunity, if regularly infected, and around their fourth year of life the severity of malaria attacks begins to decline. As evidenced from field studies, death among adults is rare in high-transmission areas, but the level of immunity may rapidly decrease when moving outside these areas (Marsh 1993).

From this follows that children up to the fifth year of life are at high risk of dying from malaria (if not appropriately treated). Also pregnant women deserve special attention, since malaria infection during pregnancy may lead to low birth weight of the infant, either through prematurity or intra-uterine growth retardation. Low birth weight, on its turn, may lead to infant mortality (Steketee et al. 2001). Furthermore, people living in areas where transmission is low or absent, such as the cool highland areas or areas at the northern and southern fringes of current malaria distribution, are also at high risk of getting severe malaria once infected.

\section{Epidemic malaria}

Historically, outbreaks of malaria have occurred in areas of unstable malaria transmission when environmental conditions were favourable (Garnham 1945; 1948). However, there is evidence that the number of outbreaks has increased during the past decades. In eastern Africa, many countries have suffered from serious epidemics with a high number of deaths (Malakooti, Biomndo and Shanks 1998; Etchegorry et al. 2001; Bonora et al. 2001; Lindblade et al. 1999). In western Kenya, malaria epidemics have spread from 3 to 15 districts during the past 13 years, often with devastating effects (Githeko and Ndegwa 2001). Some of these epidemics have been associated with extreme weather events, such as the El Niño Southern Oscillation event in 19971998, which caused heavy rainfall and flooding in eastern Africa (WMO 1999). Curiously, the same climatic event in Tanzania was associated with lower malaria incidence (Lindsay et al. 2000), suggesting that no clear-cut answer exists to what the effects of these extreme weather events are on malaria transmission.

Next to analysing single malaria outbreaks, researchers have attempted to relate historical patterns of malaria incidence to environmental changes. Increased malaria incidence over the past 30 years in the highland tea estates of western Kenya could not be explained by increased temperatures or a changed climate in general (Shanks et al. 2000; 2002). Similar observations were made for other East-African countries (Hay et al. 2002a), although a re-analysis of climatic data did show a warming trend for the same countries (Patz et al. 2002). This has led to a debate on the potential causes of malaria resurgence in eastern Africa, with global warming on the one hand and non-climatic events, such as the emergence of chloroquine resistance during the 1980s, on the other (Hay et al. 2002b; Patz et al. 2002). Although climatic changes may not be evident from the recent past, a warming climate in the near future, as predicted by various climate-change scenarios (IMAGE team 2001), may have severe consequences for malaria transmission.

With the advancement of satellite imagery and Geographical Information Systems (GIS), researchers have been able to integrate the different entomological, epidemiological and socio-economic components of malaria risk in 'easy-to-handle' data sets and 'easy-to-interpret' figures (see, e.g., MARA/ARMA 2002). This has resulted in a variety of models to forecast malaria outbreaks (so-called early-warning 
systems (Thomson and Connor 2001), study malaria transmission patterns and assess malaria risk in relation to climate change (Table 1).

Table 1. Examples of models developed to predict malaria epidemics and assess malaria risk in relation to environmental change. Input data and output parameters are given together with the area for which they were developed

\begin{tabular}{|c|c|c|c|c|}
\hline Input & Output & Area & Goal & Reference \\
\hline $\begin{array}{l}\text { Rainfall and } \\
\text { maximum } \\
\text { temperature }\end{array}$ & Epidemic risk & Kenya & Early warning & $\begin{array}{l}\text { Githeko and } \\
\text { Ndegwa (2001) }\end{array}$ \\
\hline $\begin{array}{l}\text { Malaria vector } \\
\text { density }\end{array}$ & Epidemic risk & Uganda & Early warning & $\begin{array}{l}\text { Lindblade, } \\
\text { Walker and } \\
\text { Wilson (2000) }\end{array}$ \\
\hline $\begin{array}{l}\text { Number of } \\
\text { presumptive } \\
\text { malaria cases }\end{array}$ & Epidemic risk & Madagascar & Early warning & $\begin{array}{l}\text { Albonico et al. } \\
\text { (1999) }\end{array}$ \\
\hline $\begin{array}{l}\text { Normalized } \\
\text { Difference } \\
\text { Vegetation } \\
\text { Index (NDVI) }\end{array}$ & $\begin{array}{l}\text { Malaria } \\
\text { seasonality }\end{array}$ & Kenya & $\begin{array}{l}\text { Predicting } \\
\text { malaria } \\
\text { transmission } \\
\text { seasonality } \\
\end{array}$ & $\begin{array}{l}\text { Hay, Snow and } \\
\text { Rogers (1998) }\end{array}$ \\
\hline $\begin{array}{l}\text { Rainfall and } \\
\text { temperature }\end{array}$ & $\begin{array}{l}\text { Distribution of } \\
\text { An. gambiae s.s. } \\
\text { and An. } \\
\text { arabiensis }\end{array}$ & Africa & $\begin{array}{l}\text { Facilitating } \\
\text { species-specific } \\
\text { vector-control } \\
\text { activities }\end{array}$ & $\begin{array}{l}\text { Lindsay, Parson } \\
\text { and Thomas } \\
\text { (1998) }\end{array}$ \\
\hline $\begin{array}{l}\text { Temperature, } \\
\text { NDVI, cold- } \\
\text { cloud duration } \\
\text { and elevation }\end{array}$ & $\begin{array}{l}\text { Distribution of } 5 \\
\text { sibling species } \\
\text { of the An. } \\
\text { gambiae } \\
\text { complex }\end{array}$ & Africa & $\begin{array}{l}\text { Forecasting } \\
\text { malaria }\end{array}$ & $\begin{array}{l}\text { Rogers et al. } \\
(2002)\end{array}$ \\
\hline $\begin{array}{l}\text { Rainfall and } \\
\text { temperature }\end{array}$ & $\begin{array}{l}\text { Distribution of } \\
\text { malaria } \\
\text { transmission }\end{array}$ & Africa & $\begin{array}{l}\text { Providing basis } \\
\text { for predicting } \\
\text { impact of } \\
\text { climate change }\end{array}$ & $\begin{array}{l}\text { Craig, Snow and } \\
\text { Le Sueur (1999) }\end{array}$ \\
\hline $\begin{array}{l}\text { Rainfall, } \\
\text { temperature and } \\
\text { population data }\end{array}$ & $\begin{array}{l}\text { Distribution of } \\
\text { population } \\
\text { exposed }\end{array}$ & Africa & $\begin{array}{l}\text { Providing risk } \\
\text { map for malaria } \\
\text { mortality }\end{array}$ & $\begin{array}{l}\text { Snow et al. } \\
(1999)^{1}\end{array}$ \\
\hline $\begin{array}{l}\text { Temperature and } \\
\text { rainfall }\end{array}$ & $\begin{array}{l}\text { Potential malaria } \\
\text { risk }\end{array}$ & World & $\begin{array}{l}\text { Assessing } \\
\text { malaria risk in } \\
\text { relation to } \\
\text { climate change }\end{array}$ & $\begin{array}{l}\text { Martens et al. } \\
\text { (1995) }\end{array}$ \\
\hline
\end{tabular}

Most of these models have been developed to investigate malaria risk on the continental scale of Africa. Logically, these models are too crude to assess malaria risk on local and regional scales. They have rarely been validated with real data and make many assumptions and generalizations on malaria transmission. For example, the vector of malaria is often modelled as a generic species, whereas many differences exist in the transmission capability of the main malaria vectors. In addition, most models only consider the effects of ecological variables on the adult stage, while effects on the larval stages are often neglected. Furthermore, it is still unknown which ecological variables are responsible for the temporal and spatial dynamics in species 
abundance and how this affects malaria risk. Besides, it is not clear how malaria transmission is maintained in highland areas or how epidemics may occur here.

\section{Vector biology and malaria risk on a local scale}

A means of understanding the effects of environmental factors on malaria vector biology and malaria risk is to study these on different spatial and temporal scales. This is schematically presented in Figure 1. A comparative field study was undertaken in western Kenya to investigate vector population dynamics in relation to malaria risk (Koenraadt 2003). Anopheles arabiensis Patton and Anopheles gambiae s.s. Giles, both members of the Anopheles gambiae complex, and Anopheles funestus Giles are the main vectors involved in malaria transmission in this area. In addition, western Kenya is of particular interest, since on a relatively small spatial scale there is considerable variation in altitude, climatological conditions and land-use patterns. As a consequence, the epidemiological situation of malaria varies as well (Figure 2). Here, we briefly summarize some of the most important findings of this study for our understanding on malaria transmission in highland areas.

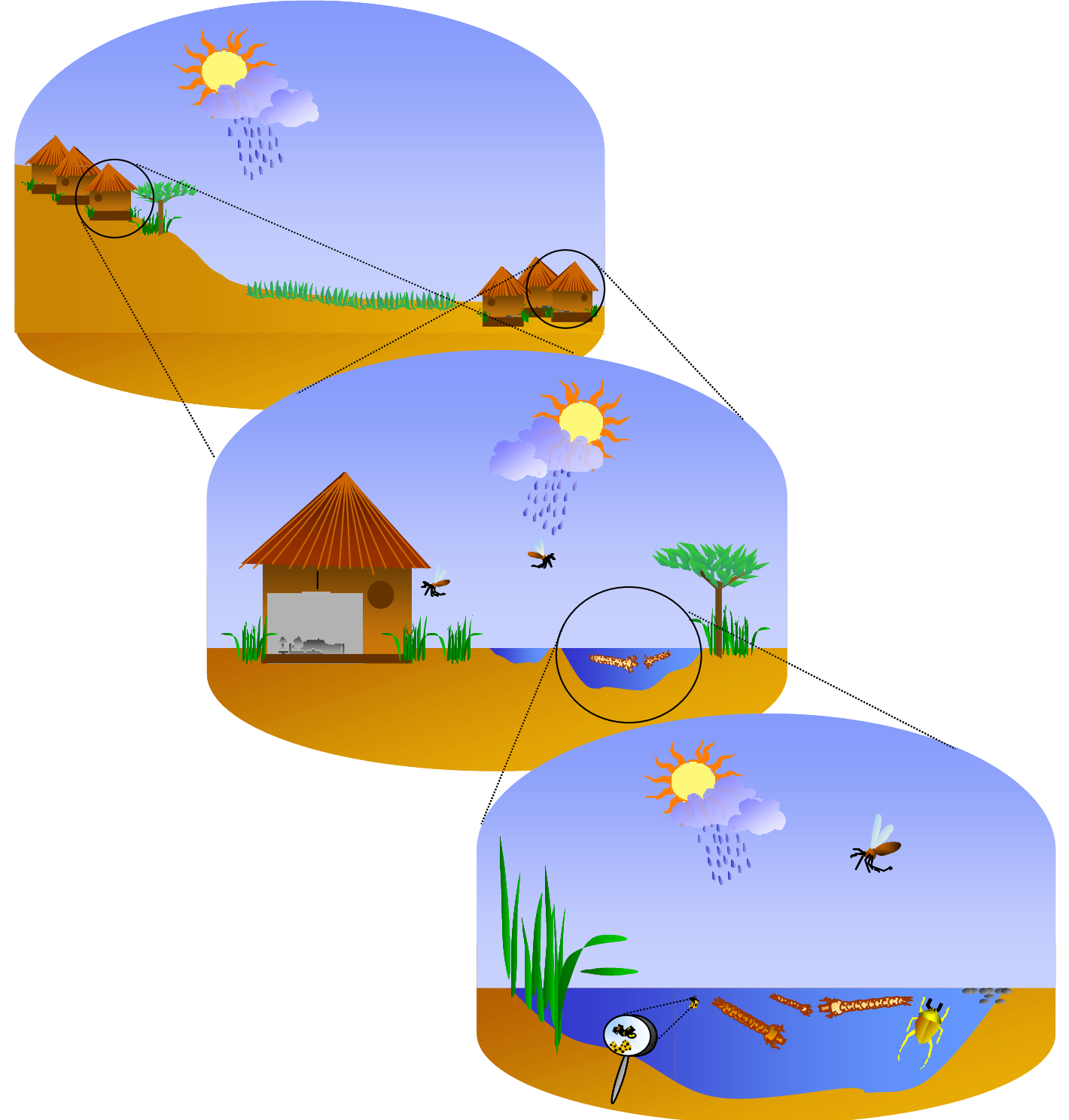

Figure 1. Schematic representation of the different scales when investigating the effect of environmental factors on vector biology and malaria risk 


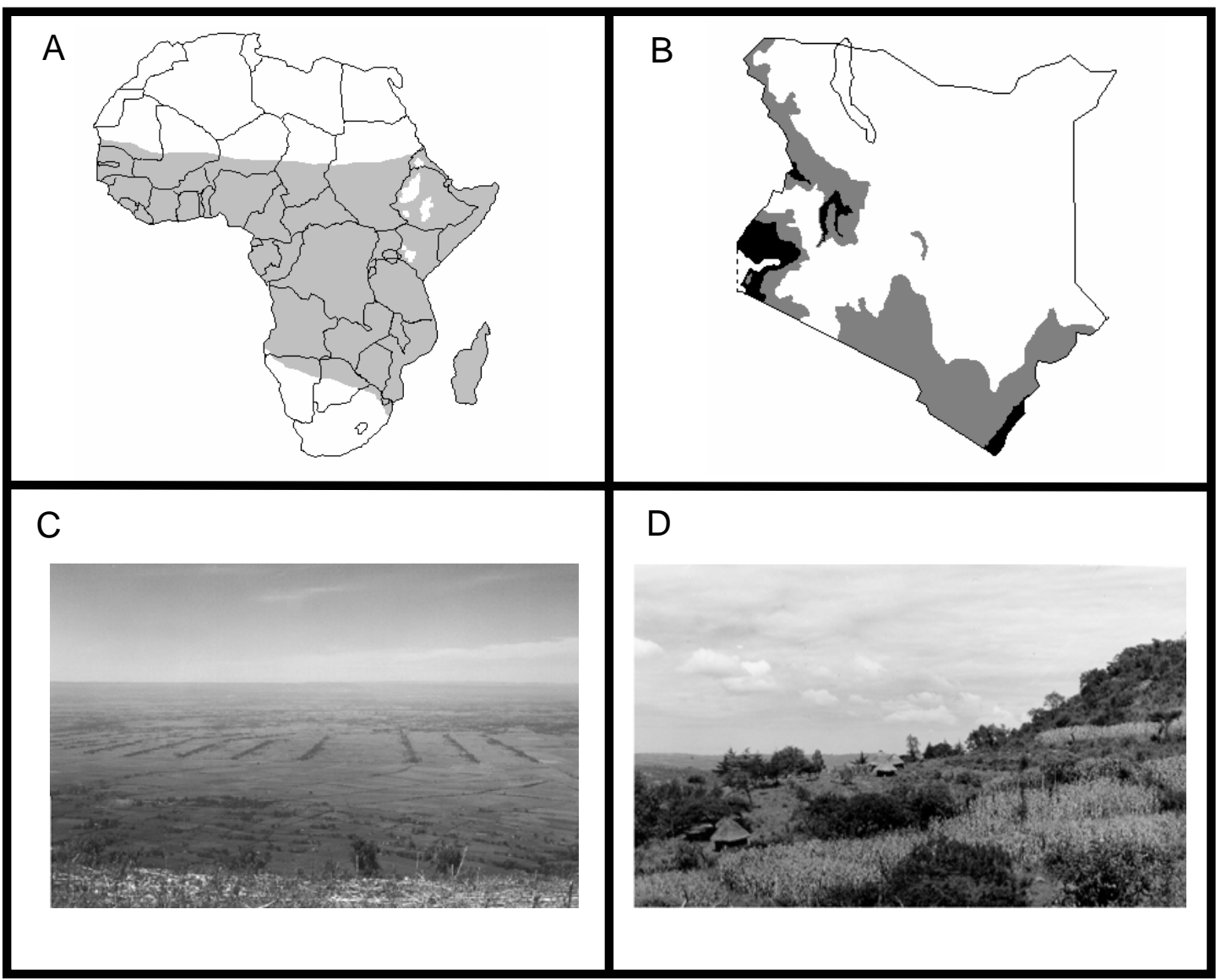

Figure 2. (A) Malaria distribution over Africa (drawn after WHO 1997); (B) epidemiological situation of malaria in Kenya. Black areas: endemic malaria; grey areas: epidemic malaria; white areas: no malaria (drawn after MARA/ARMA 2002); (C) picture of lowland area in western Kenya (approximately $1200 \mathrm{~m}$ altitude), characterized by the flat terrain and surrounded by large sugarcane plantations; (D) picture of highland area in western Kenya, 40 $\mathrm{km}$ south-east of the lowland area, characterized by a hilly landscape with mixed agriculture (approximately $1600 \mathrm{~m}$ altitude).

A striking result was that, despite the near absence of malaria vectors (5 malaria vectors were collected in 200 light-trap and 190 resting-catch collections spread over two years), malaria was transmitted throughout a two-year study period in a highland area of western Kenya (at $1600 \mathrm{~m}$ altitude). Malaria prevalence was relatively low, with a two year average of $10 \%$ among school children in the age of 5 - 10 years (minimum $0 \%$ and maximum 17\% prevalence). Larval habitats of An. gambiae s.l. were present in the highland area, although their number was rather limited compared to a lowland area $40 \mathrm{~km}$ to the northwest (at $1200 \mathrm{~m}$ altitude). For example, only 7 An. gambiae s.l. breeding habitats were identified during a 4-month study within an area of approximately $4 \mathrm{~km}^{2}$, whereas on a $1.7-\mathrm{km}$ dirt road in a lowland area more than 100 An. gambiae s.l. breeding habitats could be identified on a single sampling occasion (Koenraadt, Githeko and Takken 2004). Interestingly, three of the seven identified breeding sites in the highland area were the result of human conduct: larvae were found in sites that were the result of leaking taps or in sites that were regularly filled by people for domestic purposes or to provide drinking water for cattle. All An. gambiae s.l. larvae were found in the presence of larvae of An. christyi Newstead \& Carter. To what extent this association affected vector dynamics in the area, remains 
unclear. Experimental studies showed that larvae of An. gambiae s.s. and An. arabiensis did not survive the cool environmental temperatures in the highland area, whereas adults of both species (placed in cages) survived inside local houses in the same area (Koenraadt 2003). These studies also showed that adults of An. gambiae s.s. survived longer than An. arabiensis in the highland area, whereas the reverse was true for the lowland area. In addition, larvae of An. arabiensis developed faster to the pupal stage than An. gambiae s.s. in the lowland area, consistent with earlier findings under laboratory conditions (Schneider, Takken and McCall 2000). The combined experimental and field observations suggested that the contribution of a locally breeding vector population to malaria transmission in the highland area was negligible. More likely, the few infections among school children were caused by infected mosquitoes that immigrated from areas where environmental conditions are more favourable. Since children rarely moved out of the study area, we ruled out the possibility that their infections were obtained through visits to lower areas. Population-genetic studies on vectors collected in highland areas and in the nearby lowland areas may give more insight in the degree of gene flow and thus the amount of genetic divergence between highland and lowland mosquitoes (Wang, Kafatos and Zheng 1999; Lehmann et al. 1997, Lanzaro pers. comm.).

It should be emphasized that the transmission process described above may not be valid for all highland areas in eastern Africa. Local variation may arise as a result of differences in (i) geography, e.g. highland areas may be surrounded by steep escarpments or valley bottoms, and (ii) land cover/land use: suitability of the environment for mosquito survival and dispersal will differ between, for example, relatively bare highland areas, areas surrounded by marshes and areas with large-scale agriculture. Several studies have focussed on malaria transmission in high-altitude areas in Kenya, Tanzania and Uganda, and the role of vectors therein. However, these studies were limited to collections of the adult stages (Bødker 2000; Lindblade et al. 1999; 2000; Minakawa et al. 2002; Shililu et al. 1998). Therefore, most of these studies could not confirm the true existence of transmission by a local population or transmission by a population which immigrated from an adjacent area.

The insights obtained on malaria transmission in a highland area, allow us to speculate in more detail on the potential impact of environmental change on malaria risk. An increase in temperature in the near future, either as a result of global warming or land-use changes affecting microclimate, may enhance larval survival. As a result, local vector populations may establish in sufficient numbers to cause epidemics. This is supported by observations of Garnham (1945), who speculated that epidemics occurring at high altitudes may result from temporarily favourable climatic conditions that allow breeding of An. gambiae. On a larger time scale, it may be the more efficient vector An. gambiae s.s. settling first in highland areas, because this species survives better than An. arabiensis under present highland conditions.

Temperature and vector density have been used to develop early warning systems based on data from past epidemics (Githeko and Ndegwa 2001; Lindblade, Walker and Wilson 2000). Our results demonstrate that monitoring the larval stages may provide an additional means to assess the likelihood of outbreaks of malaria. For example, a warning based on increased environmental temperatures may be more confident if it is associated with high densities of local breeding sites in which larvae survive. 


\section{Final remarks}

From our studies it became clear that many biological processes underlying the rise and fall of malaria vector populations are still poorly understood. Besides the mentioned differences in larval development and adult survival in response to different environmental conditions, other factors, such as competition among An. gambiae s.l. larvae occupying a site (Koenraadt and Takken 2003) and larval behaviour in response to drought (Koenraadt et al. 2003) may also play an important role in determining the size and species composition of vector populations. Although the evidence seems to point towards the establishment of vector populations in a highland area from nearby lower areas when environmental conditions are suitable, the degree of immigration remains to be studied. Finally, the phenomena observed in the highland area in western Kenya need to be evaluated for other areas in eastern Africa. Only then, local malaria risk models can be reliably upscaled to the regional and continental scale.

\section{References}

Albonico, M., De Giorgi, F., Razanakolona, J., et al., 1999. Control of epidemic malaria on the highlands of Madagascar. Parassitologia, 41 (1/3), 373-376.

Bødker, R., 2000. Variation in malaria risk in the Usambara Mountains, Tanzania. PhD Thesis University of Copenhagen, Copenhagen.

Bonora, S., De Rosa, F.G., Boffito, M., et al., 2001. Rising temperature and the malaria epidemic in Burundi. Trends in Parasitology, 17 (12), 572-573.

Craig, M.H., Snow, R.W. and Le Sueur, D., 1999. A climate-based distribution model of malaria transmission in sub-Saharan Africa. Parasitology Today, 15 (3), 105-111.

Day, K.P. and Marsh, K., 1991. Naturally acquired immunity to Plasmodium falciparum. Immunology Today, 12 (3), A68-A71.

Etchegorry, M.G., Matthys, F., Galinski, M., et al., 2001. Malaria epidemic in Burundi. Lancet, 357 (9261), 1046-1047.

Garnham, P.C.C., 1945. Malaria epidemics at exceptionally high altitudes in Kenya. The British Medical Journal, 11, 45-47.

Garnham, P.C.C., 1948. The incidence of malaria at high altitudes. Journal of the National Malaria Society, 7, 275-284.

Githeko, A.K., Lindsay, S.W., Confalonieri, U.E., et al., 2000. Climate change and vector-borne diseases: a regional analysis. Bulletin of the World Health Organization, 78 (9), 1136-1147.

Githeko, A.K. and Ndegwa, W., 2001. Predicting malaria epidemics in the Kenyan highlands using climate data: a tool for decision makers. Global Change \& Human Health, 2 (1), 54-63. [http://www.ogp.noaa.gov/mpe/csi/esd/ africa/fundproj/health/malaria_epidemic.pdf]

Gupta, S., Snow, R.W., Donnelly, C.A., et al., 1999. Immunity to non-cerebral severe malaria is acquired after one or two infections. Nature Medicine, 5 (3), 340343.

Hay, S.I., Cox, J., Rogers, D.J., et al., 2002a. Climate change and the resurgence of malaria in the East African highlands. Nature, 415 (6874), 905-909.

Hay, S.I., Rogers, D.J., Randolph, S.E., et al., 2002b. Hot topic or hot air? Climate change and malaria resurgence in East African highlands. Trends in Parasitology, 18 (12), 530-534. 
Hay, S.I., Snow, R.W. and Rogers, D.J., 1998. Predicting malaria seasons in Kenya using multitemporal meteorological satellite sensor data. Transactions of the Royal Society of Tropical Medicine and Hygiene, 92 (1), 12-20.

IMAGE team, 2001. The IMAGE 2.2 implementation of the SRES scenarios: a comprehensive analysis of emissions, climate change and impacts in the 21 st century. RIVM, Bilthoven. RIVM Rapport no. 481508018.

Koenraadt, C.J., Githeko, A.K. and Takken, W., 2004. The effects of rainfall and evapotranspiration on the temporal dynamics of Anopheles gambiae s.s. and Anopheles arabiensis in a Kenyan village. Acta Tropica, 90 (2), 141-153.

Koenraadt, C.J., Paaijmans, K.P., Githeko, A.K., et al., 2003. Egg hatching, larval movement and larval survival of the malaria vector Anopheles gambiae in desiccating habitats. Malaria Journal, $2 \quad(1), \quad 20$ p. [http://www.malariajournal.com/content/2/1/20]

Koenraadt, C.J. and Takken, W., 2003. Cannibalism and predation among larvae of the Anopheles gambiae complex. Medical and Veterinary Entomology, 17 (1), 61-66.

Koenraadt, C.J.M., 2003. Mosquitoes, men and malaria in Kenya: a study on ecological factors affecting malaria risk. PhD Thesis Wageningen University, Wageningen.

Lehmann, T., Besansky, N.J., Hawley, W.A., et al., 1997. Microgeographic structure of Anopheles gambiae in western Kenya based on mtDNA and microsatellite loci. Molecular Ecology, 6 (3), 243-253.

Lindblade, K.A., Walker, E.D., Onapa, A.W., et al., 1999. Highland malaria in Uganda: prospective analysis of an epidemic associated with El Niño. Transactions of the Royal Society of Tropical Medicine and Hygiene, 93 (5), 480-487.

Lindblade, K.A., Walker, E.D., Onapa, A.W., et al., 2000. Land use change alters malaria transmission parameters by modifying temperature in a highland area of Uganda. Tropical Medicine and International Health, 5 (4), 263-274.

Lindblade, K.A., Walker, E.D. and Wilson, M.L., 2000. Early warning of malaria epidemics in African highlands using Anopheles (Diptera: Culicidae) indoor resting density. Journal of Medical Entomology, 37 (5), 664-674.

Lindsay, S.W., Bødker, R., Malima, R., et al., 2000. Effect of 1997-98 El Niño on highland malaria in Tanzania. Lancet, 355 (9208), 989-990.

Lindsay, S.W., Parson, L. and Thomas, C.J., 1998. Mapping the ranges and relative abundance of the two principal African malaria vectors, Anopheles gambiae sensu stricto and An. arabiensis, using climate data. Proceedings of the Royal Society of London. Series B. Biological Sciences, 265 (1399), 847-854.

Malakooti, M.A., Biomndo, K. and Shanks, G.D., 1998. Reemergence of epidemic malaria in the highlands of western Kenya. Emerging Infectious Diseases, 4 (4), 671-676.

MARA/ARMA, 2002. MARA LITe: Mapping Malaria Risk in Africa Low-end Information Tool. South African Medical Research Council, Malaria Research Programme. [http://www.arma.org.za/lite.htm]

Marsh, K., 1993. Immunology of human malaria. In: Gilles, H.M., Warrell, D.A. and Bruce-Chwatt, L.J. eds. Bruce-Chwatt's essential malariology. Arnold, London, 60-77.

Martens, W.J., 1998. Health impacts of climate change and ozone depletion: an ecoepidemiologic modeling approach. Environmental Health Perspectives, 106 (Suppl. 1), 241-251. 
Martens, W.J., Niessen, L.W., Rotmans, J., et al., 1995. Potential impact of global climate change on malaria risk. Environmental Health Perspectives, 103 (5), 458-464.

Martens, W.J., Slooff, R. and Jackson, E.K., 1997. Climate change, human health, and sustainable development. Bulletin of the World Health Organization, 75 (6), 583-588.

Minakawa, N., Sonye, G., Mogi, M., et al., 2002. The effects of climatic factors on the distribution and abundance of malaria vectors in Kenya. Journal of Medical Entomology, 39 (6), 833-841.

Patz, J.A., Graczyk, T.K., Geller, N., et al., 2000. Effects of environmental change on emerging parasitic diseases. International Journal of Parasitology, 30 (12/13), 1395-1405.

Patz, J.A., Hulme, M., Rosenzweig, C., et al., 2002. Climate change: regional warming and malaria resurgence. Nature, 420 (6916), 627-628; discussion 628.

Patz, J.A. and Reisen, W.K., 2001. Immunology, climate change and vector-borne diseases. Trends in Immunology, 22 (4), 171-172.

Roberts, D.J., Biggs, B.A., Brown, G., et al., 1993. Protection, pathogenesis and phenotypic plasticity in Plasmodium falciparum malaria. Parasitology Today, 9 (8), 281-286.

Rogers, D.J., Randolph, S.E., Snow, R.W., et al., 2002. Satellite imagery in the study and forecast of malaria. Nature, 415 (6872), 710-715.

Schneider, P., Takken, W. and McCall, P.J., 2000. Interspecific competition between sibling species larvae of Anopheles arabiensis and An. gambiae. Medical and Veterinary Entomology, 14 (2), 165-170.

Shanks, G.D., Biomndo, K., Hay, S.I., et al., 2000. Changing patterns of clinical malaria since 1965 among a tea estate population located in the Kenyan highlands. Transactions of the Royal Society of Tropical Medicine and Hygiene, 94 (3), 253-255.

Shanks, G.D., Hay, S.I., Stern, D.I., et al., 2002. Meteorologic influences on Plasmodium falciparum malaria in the Highland Tea Estates of Kericho, Western Kenya. Emerging Infectious Diseases, 8 (12), 1404-1408.

Shililu, J.I., Maier, W.A., Seitz, H.M., et al., 1998. Seasonal density, sporozoite rates and entomological inoculation rates of Anopheles gambiae and Anopheles funestus in a high-altitude sugarcane growing zone in Western Kenya. Tropical Medicine and International Health, 3 (9), 706-710.

Snow, R.W., Craig, M.H., Deichmann, U., et al., 1999. A preliminary continental risk map for malaria mortality among African children. Parasitology Today, 15 (3), 99-104.

Steketee, R.W., Nahlen, B.L., Parise, M.E., et al., 2001. The burden of malaria in pregnancy in malaria-endemic areas. American Journal of Tropical Medicine and Hygiene, 64 (1/2 Suppl.), 28-35.

Thomson, M.C. and Connor, S.J., 2001. The development of Malaria Early Warning Systems for Africa. Trends in Parasitology, 17 (9), 438-445.

Wang, R., Kafatos, F.C. and Zheng, L., 1999. Microsatellite markers and genotyping procedures for Anopheles gambiae. Parasitology Today, 15 (1), 33-37.

Warrell, D.A., 1993. Clinical features of malaria. In: Gilles, H.M., Warrell, D.A. and Bruce-Chwatt, L.J. eds. Bruce-Chwatt's essential malariology. Arnold, London, 35-49. 


\section{Chapter 7}

WHO, 1997. World malaria situation in 1994. Weekly epidemiological record (36), 269-276. [http://www.who.int/docstore/wer/pdf/1997/wer7236.pdf]

WMO, 1999. The 1997-1998 El Niño event: a scientific and technical retrospective.

World Meteorological Organization. WMO Report no. 905. [http://www.wmo.ch/nino/WMO905-e.pdf] 